\title{
PENERAPAN TEHNOLOGI INSEMINASI BUATAN MENGGUNAKAN SPERMA SEXING PADA TERNAK SAPI DI KECAMATAN LINGSAR KABUPATEN LOMBOK BARAT
}

\author{
Implementation of Artificial Insemination Technology Using Sexing Sperms In \\ Cow Livestock In Lingsar Sub-District, West Lombok Disrict
}

\author{
Lukman HY*, Rodiah, Enny Yuliani, Lalu Ahmad Zaenuri dan Iwayan Lanus Sumadiasa \\ Program Studi Produksi Ternak Universitas Mataram \\ Jalan Majapahit Nomor 62, Mataram 83125 \\ *Alamat korespondensi: hylukman@yahoo.com
}

(Tanggal Submission: 15 Januari 2020, Tanggal Accepted: 30 Agustus 2020)

\begin{abstract}
ABSTRAK
Peningkatan mutu reproduksi pada kegiatan perternakan sapi perlu terus menerus digalakkan. Hal tersebut agar terciptanya efisiensi pada usaha produksi ternak sehingga menghasilkan keuntungan finansial yang lebih baik. Kegiatan pengabdian kepada masyarakat ini bertujuan untuk meningkatkan mutu genetik pada ternak sapi melalui inseminasi buatan menggunakan tekhnologi sperma sexing. Kegiatan ini dilakukan melalui penyuluhan, ceramah dan diskusi. Peserta yang menjadi target pelaksanaan kegiatan adalah peternak sapi yang berkecimpung pada bidang tekhnologi reproduksi. Hasil evaluasi menunjukkan bahwa kegiatan pengabdian pada masyarakat ini berjalan cukup baik. Respon dan antusiasme peserta penyuluhan dalam diskusi sangat baik. Penilaian sangat baik karena sambutan dari tokoh atau pemuka masyarakat untuk dapat merealisasikan pengetahuan tentang IB menggunakan sperma sexing pada ternaknya. Kesimpulan dari kegiatan ini adalah terjadinya peningkatan pengetahuan dan pemahaman peserta tentang teknologi inseminasi buatan menggunakan metode sperma sexing pada ternak sapi. Penilaian ini berdasarkan respon peserta dan pemuka masyarakat, sehingga hal ini merupakan faktor pendukung keberhasilan pelaksanaan IB pada waktu yang akan datang.
\end{abstract}

kata kunci: inseminasi buatan, sperma sexing, ternak sapi, kecamatan lingsar

\section{PENDAHULUAN}

Sapi Bali (Bossondaicus) merupakan salah satu sapi potong asli Indonesia hasil domestikasi dari banteng (Bos-bibosbanteng) dan memiliki potensi yang besar untuk mensuplai sumber protein esensial bagi masyarakat Indonesia. Direktorat Jenderal Peternakan Republik Indonesia menyatakan bahwa populasi sapi Bali sampai tahun 2010 ditaksir sekitar 526.031 juta ekor. Sapi Bali tersebar luas diseluruh wilayah Indonesia dan mendominasi wilayah Sulawesi Selatan, Timor, Bali dan NTB (Chamdi, 2004). Masyarakat memelihara sapi Bali sebagai tabungan, sebagai sapi produksi daging, ternak pekerja di sawah. Penerapan teknologi reproduksi melalui Inseminasi Buatan dengan sperma sexing menggunakan pejantan unggul merupakan upaya untuk memacu pengembangan peternakan secara efektif dan efisien dalam meningkatkan produktivitas ternak. 
Sexing atau pemisahan sperma adalah kegiatan yang bertujuan untuk memisahkan spermatozoa yang membawa sifat kelamin jantan dengan betina. Pemilihan teknologi sexing spermatozoa merupakan salah satu pilihan yang tepat dalam rangka peningkatan efisiensi reproduksi ternak yang mampu meningkatkan efisiensi usaha peternakan baik dalam skala peternakan rakyat maupun dalam skala peternakan komersial. IB sexing adalah peternak dapat memilih apakah pedet yang akan lahir jenis betina atau jantan, tergantung tujuan pemeliharaan apakah untuk penggemukan atau bibit. Salah satu sasaran dalam bidang reproduksiternakadalah memproduksi anak yang mempunyai jenis kelamin sesuai yang diinginkan. Pengaturan rasioseks yang diproduksi secara komersial untuk menghasilkan anak jantan atau betina superior sebagai induk untuk penerus keturunanataubibitjantan (Yuliani dan Lukman HY 2013 ).

Penerapan teknologi IB sexing telah terbukti dapat digunakan untuk meningkatkan mutu genetik dan pendapatan petani peternak, (Mc. Caughey and Cooper, 1980 ; Hafez, 2008). Upaya untuk meningkatkan keberhasilan IB dapat dilakukan melalui pemilihan betina produktif dengan siklus reproduksi teratur, deteksi estrus yang benar, serta deposisi semen di tempat dan pada waktu yang tepat (Inonu, 2014).

Salah satu penyebab rendahnya angka pembuahan dari hasil IB adalah waktu pelaksanaan inseminasi yang tidak tepat waktu akibat dari kesalahan deteksi estrus (Partodihardjo, 1992). Kesulitan peternak dalam mendeteksi berahi disebakan adanya variasi yang luas terhadap tandatanda estrus, baik lama maupun intensitasnya. Deteksi berahi dapat dilakukan dengan beberapa cara yaitu secara visual oleh manusia dengan melihat tanda-tada berahi pada betina seperti mendorongdorong temannya, menaiki temannya atau dinaiki diam, ekor naik, gelisah, vulva).
Berdasarkan hasil penelitian bahwa Sapi bali merupakan sapi yang paling subur dan cocok untuk dikembangkan di daerah tropis dan mendukung program pemerintah pusat/daerah untuk pencapaian Swasembada daging (Lukman dkk, 2003). Produktivitas sapi bali cukup baik sehingga berpotensi untuk dikembangkan menjadi suatu peternakan komersial. Penerapan teknologi inseminasi buatan menggunakan sperma sexing pada ternak sapi untuk meningkatkan pengetahuan dan pendapatan peternak dapat memberikan motivasi kepada peternak untuk melakukan dari cara tradisional beralih ke cara teknologi yang sesuai dengan kondisi lapangan.

\section{METODE KEGIATAN}

\section{Metode pendekatan}

Kegiatan pengabdian kepada masyarakat ini dilaksanakan di desa Karan Bayan Kecamatan Lingsar Kabupaten Lombok Barat. Metode pendekatan yang dilakukan adalah Innovative Approach yang mengutamakan peserta terlibat langsung secara aktif. Bentuk penyuluhan dengan kegiatan penyampaian materi berupa ceramah dan diskusi (tanya jawab) tentang penerapan teknologi inseminasi buatan menggunakan sperma sexing pada ternak sapi untuk meningkatkan pengetahuan dan pendapatan peternak.

Program penunjang di antaranya adalahpelatihan, ketrampilan teknologi, bimbingan manajemen usaha, informasi pasar, dan perkuatan modal.

\section{Pengumpulan Data}

Pengumpulan data dilakukan dengan cara observasi ke daerah langsung dan melakukan wawancara kepada peternak sapi dan petani, dan juga wawancara kepada kepala desa dan kepala dusun.

\section{Analisa Data}

Dari hasil observasi dan wawancara yang dilakukan di lapangan, dapat diketahui kendala- 
kendala dan permasalahan yang dapat diperbaiki dan ditingkatkan kinerjanya.

\section{Pelaksanaan Kegiatan}

1. Penyampaian materi:

a. Daya fertilitas induk sapi bali

Daya fertilitas yang tinggi adalah dasar dan tujuan setiap program peternakan. Semakin banyak sapi betina yang kawin berulang (repeat breeders), maka akan sangat merugikan baik bagi pelaksana IB maupun bagi peternak. Penentuan penilaian daya fertilitas ternak setelah IB dapat diketahui angka konsepsi. Faktor yang menentukan adalah 3 faktor yaitu kesuburan pejantan, kesuburan betina dan teknik inseminasi. Serviceper Conception untuk membandingkan efisiensi relative dari proses reproduksi di antara individu sapi betina yang subur,sering dipakai penilaian service yang dibutuhkan oleh seekor betina sampai terjadinya kebuntingan atau konsepsi (Yuliani, 2009).

b. IB sexing

Peternak dapat memilih apakah pedet yang akan lahir jenis betina atau jantan, tergantung tujuan pemeliharaan apakah untuk penggemukan atau bibit. Sexing atau pemisahan sperma adalah kegiatan yang bertujuan untuk memisahkan spermatozoa yang membawa sifat kelamin jantan dengan betina. Pemilihan teknologi sexing spermatozoa merupakan salah satu pilihan yang tepat dalam rangka peningkatan efisiensi reproduksi ternak yang mampu meningkatkan efisiensi usaha peternakan baik dalam skala peternakan rakyat maupun dalam skala peternakan komersial.

\section{Diskusi dan Tanya Jawab}

Diskusi dan tanya jawab tentang pelaksanaan IB dibutuhkan pendeksian berahi yang tepat dan akurat untuk menentukan waktu yang tepat untuk inseminasi buatan. IB sexing adalah upaya meningkatkan pengetahuan dan keterampilan para peternak sapi dengan menjelaskan pentingnya penerapan reproduksi terpadu melalui IB

\section{Evaluasi Pelaksanaan Kegiatan}

Evaluasi dilakukan dalam dua tahap yaitu selama kegiatan penyuluhan dengan memantau respon peserta dalam diskusi dan setelah penyuluhan dengan pembinaan tambahan melalui kunjungan setelah kegiatan ketika diperlukan. Bentuk atau kriteria evaluasi yang dilakukan adalah dengan melihat kehadiran peserta, respon peserta melalui jalannya tanya jawab atau diskusi.

\section{HASIL DAN PEMBAHASAN}

Tujuan pemeliharaan sangat menentukan dalam pemilihan bibit yang akan lahir dalam IB sexing (Yuliani dan Lukman HY, 2013). Pemilihan bibit jantan dilakukan apabila peternak menginginkan bibit sapi untuk dijadikan sapi potong. Pemilihan bibit betina dilakukan apabila peternak menginginkan sapi perah. Hal tersebut diilustrasikan melalaui Gambar 1.

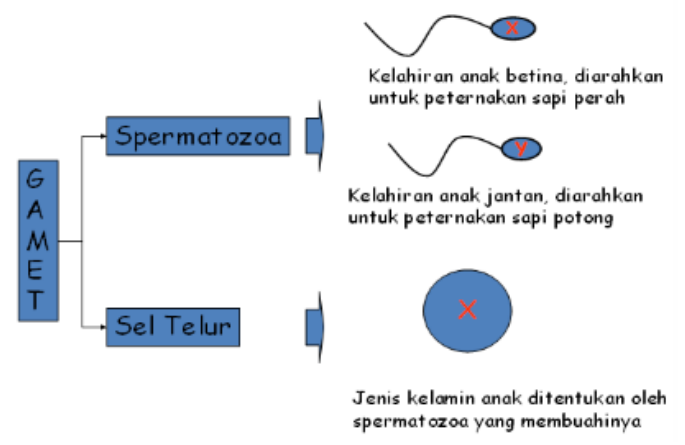

Gambar 1. Pemilihan spermatozoa dalam menentukan jenis kelamin anak yang lahir 


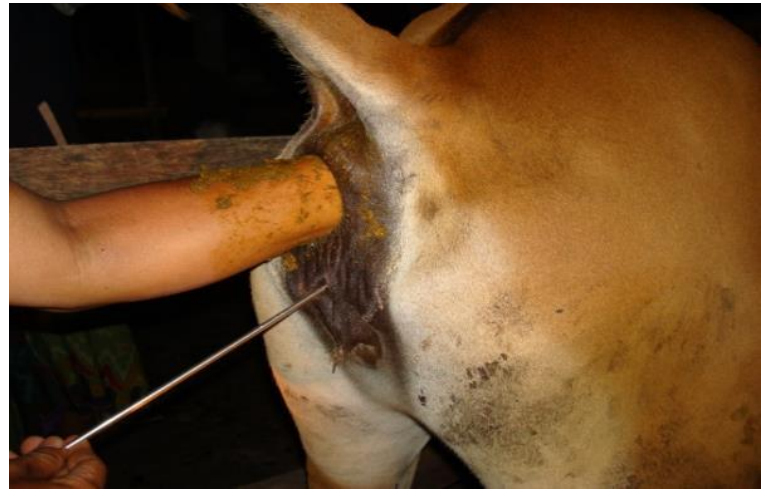

Gambar 2. Inseminasi buatan menggunakan spermatozoa sexing

Peternak dapat memilih apakah pedet yang akan lahir jenis betina atau jantan, tergantung tujuan pemeliharaan apakah untuk penggemukan atau bibit. Sexingataupemisahan spermaadalah kegiatanyang bertujuan untukmemisahkan spermatozoa yangmembawasifatkelamin jantandenganbetina (Yuliani dan Lukman HY, 2013). Peternak jika ingin memilih pedet yang akan lahir untuk dijadikan bibit maka peternak akan memilih bibit yang betina.

Pengamatan dan evaluasi dari materi penyuluhan yang telah disampaikan, ternyata minat dan respon peserta penyuluh untuk memperhatikan materi yang disampaikan oleh para tim penyuluh cukup tinggi, terbukti dari pertanyaan-pertanyaan yang dilontarkan oleh peserta penyuluh dan kehadiran sewaktu penyampaian penyuluhan menunjukkan bahwa tujuan dari kegiatan ini adalah untuk memberikan ilmu pengetahuan pada para peternak tentang penerapan tenologi inseminasi buatan serta IB sexing pada ternak sapi.

Umumnya sebagian besar peserta penyuluh, menganggap penyuluhan ini sangat bermanfaat, untuk diterapkan dalam kegiatan beternak sehari-hari untuk mendapatkan pendapatan peternak yang lebih baik. Anak hasil inseminasi buatan (IB) pada umur 2-3 bulan nilainya hampir sama harga induknya. Dari hasil yang telah disampaikan ternyata peserta ingin menerapkan/mempraktekan terutama pada masing-masing ternaknya sendiri.

Faktor penghambat dalam pelaksanaan pengabdian ini tidak ditemukan. Hal ini dikarenakan peserta penyuluh mengerti bahasa/menguasai yang dipergunkan dalam penyampaian materi yaitu bahasa indonesia dan bahasa daerah. Tempat pelaksanaannya di lingkungan mereka sendiri pada kandang kelompok dan di Dusun Karan Bayan Kecamatan Lingsar.

Faktor pendorong yang menunjang kelancaran jalannya penyuluhan ini adalah adanya kerja sama yang baik antara peserta penyuluh dengan tokoh masyarakat Kepala Dusun, dan tokoh masyarakat setempat. Topik yang disajikan merupakan hal yang menarik dan baru untuk peserta penyuluh sehingga dirasakan perlu untuk diketahui oleh para peternak untuk meningkatkan produktivitas dalam usaha beternak sapi.

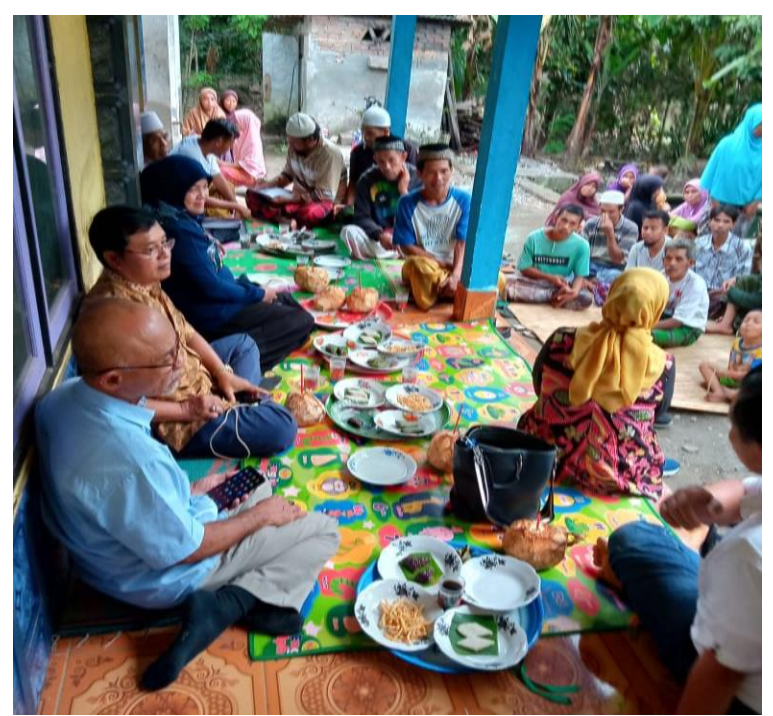

Gambar 3. Sambutan Kepala Desa dan Kepala Dusun Karan Bayan pada kegiatan pengabdian kepada masyarakat 


\section{KESIMPULAN DAN SARAN}

\section{Kesimpulan}

Kegiatan pengabdian semacam ini dapat membantu petani peternak dalam meningkatkan produktivitas melalui IB/IB sexing dan perbaikan pengelolaan managemen reproduksi ternak sapi dan meningkatkan kesejahteraan peternak khususnya di Desa Karan Bayan

\section{Saran}

Melihat minat dan respon peserta penyuluh terhadap materi yang disuluhkan maka pihak Universitas Mataram perlu mendukung untuk memperluas jaringan penyuluhan kepada petani peternak/kelompok peternak melaui pendekatan formal maupun informal. Melihat minat dan respon peserta penyuluh terhadap materi yang disuluhkan maka pihak Universitas Mataram perlu mendukung untuk memperluas jaringan penyuluhan kepada kelompok peternak melaui pendekatan formal maupun informal.

\section{DAFTAR PUSTAKA}

Chamdi, A.N.P., 2004. Krateristik Sumberdaya Genetik Ternak sapi Bali dan Alternatif pola konservasinya: 70-75.

Caughey. E, C.W. J and Cooper, R.J. 1980 An Assement Gy Progesteron Assay of Oestries
Detection Dairy Cows Vet. Rec. 107 : $508-$ 510.

Hafez, E.S.E and B. Hafez, 2008. Spermatozoa and Seminal Plasma. In Reproduction in Farm Animals. Hafez, B. and E.S.E. Hafez 7 th ed. Blackwell Publishing. USA: 96-102.

Inonu, 2014.Sustainable Livestock Production In The Prespective Of Food Security, Policy, Genetic Resources, And Climate Change

Partodihardjo S. 1992. Ilmu Reproduksi Ternak. Mutiara Sumber Widya. Jakarta.

Lukman HY, Syahibudin, I.W.L. Sumadiasa dan Rodiah, 2003. Studi Sifat-Sifat Reproduksi Sapi Bali Yang di Pelihara secara Tradisional di Kabupaten Lombok Tengah. Majalah Ilmiah Fakultas Peternakan, Universitas Mataram, Vol. 4(2).

Yuliani, E. 2009. Daya Fertilitas Sperma Sexing Kambing Peranakan Ettawa Setelah Simpan Dingin dan Simpan Beku. J. Ilmiah Ilmu-ilmu Peternakan. No Akreditasi: 34/DIKTI/Kep/2003.Tanggal, 10-06-2003.

Yuliani, E dan Lukman HY., 2013. Application of Sperm Sexing Base don Antioxidants to the Quality, Integrity of the Membrane and Fertility of Bali Cattle). Seminar Nasional Tehnologi Peternakan dan Veteriner. 